ROCZNIKI HUMANISTYCZNE

Tom LXVII, zeszyt $9-2019$

DOI: http://dx.doi.org/10.18290/rh.2019.67.9-5

AGNIESZKA PATERSKA-KUBACKA

\title{
CHIŃSKIE MITY I WIERZENIA ZWIĄZANE Z KSIĘŻYCEM (YUÈ 月, YUÈLIANG 月亮)
}

\author{
CHINESE MYTHS AND BELIEFS ASSOCIATED WITH THE MOON \\ $(Y U \grave{E}$ 月, YUĖLIANG 月亮)
}

\begin{abstract}
A bstract. This article is an attempt to gather in one place the most popular myths, symbols and characters associated with the Moon. It has been divided into two parts. The first part refers to legends and presents residents of the Silver Globe (Chang'e, bunny/rabbit, toad/frog, Wu Gang) and objects located there (cinnamon tree, Moon Palace). The second part is an attempt to scientifically verify these beliefs and myths. It refers to such issues as frog deity and Moon deity in the context of femininity, fertility and immortality. Next, it deals with the relationship between Moon and number "seven." The last two sections briefly discuss the traditional Chinese holidays, connected with the Moon (Mid Autumn Festival and Double Seventh Festival) and the Chinese Lunar Exploration Project, which could be a modern proof of the Chinese people's attachment to traditions and popular beliefs (names of space vehicles).
\end{abstract}

Key words: Moon; Chang'e; toad/frog; hare/rabbit; Wu Gang; cinnamon tree; seven.

\section{MITY}

Według słownika chińskich symboli Wolframa Eberharda ${ }^{1}$ Księżyc jest związany z żeńskim żywiołem yin (yīn 阴). Także bóg Księżyca jest rodzaju żeńskiego. Wynika to m.in. z faktu, że Księżyc „rodzi się” na zachodzie, a kierunek zachodni także jest postrzegany jako żeński. Ponadto elementowi yin jest również przypisana jesień, a Chińczycy uważają, że jesienią Księżyc jest najpiękniejszy².

Dr Agnieszka Paterska-Kubacka - Uniwersytet im. Adama Mickiewicza w Poznaniu, Wydział Neofilologii, Katedra Orientalistyki; adres do korespondencji: ul. Grunwaldzka 6, 60-780 Poznań; email: agpater@amu.edu.pl; ORCID: https://orcid.org/0000-0002-0491-5553.

${ }^{1}$ Wolfram Eberhard, Symbole chinskie: słownik: obrazkowy język Chińczyków, przeł. Renata Darda (Kraków: UnIVERsiTAS, 1996), 119.

${ }^{2}$ Według chińskiego kalendarza księżycowego jesień wypada pomiędzy sierpniem a listopadem kalendarza gregoriańskiego — w 2018 r. rozpoczęła się 7 sierpnia, a zakończyła 6 listopada. 
Dalej autor podaje, że tradycyjnie jesienią odbywały się egzekucje, co miało korespondować z obumierającą o tej porze roku przyrodą. „Księżyc porównywany jest $\mathrm{z}$ traceniem złoczyńców, Słońce zaś - z cnotą dobrych ludzi”. Wreszcie, na zasadzie analogii, ponieważ Słońce było symbolem cesarza, Księżyc mógł reprezentować cesarzową ${ }^{3}$.

Za pierwszą boginię Księżyca uznaje się Nüwę (Nüwā 女娲), która była także pierwszą boginią (kobietą) w chińskiej mitologii, stworzycielką ludzi ${ }^{4}$.

Starożytni Chińczycy wierzyli, że księżyców jest dwanaście, co miało odpowiadać liczbie miesięcy księżycowych w roku. Księżyce owe były kobietami, córkami cesarza Juna (Dijùn 帝俊), władcy wschodniego nieba ${ }^{5}$.

W mniemaniu Chińczyków Księżyc (ostatecznie jeden, mity nie wyjaśniają, co się stało z pozostałymi jedenastoma) jest dość gęsto zaludnionym satelita, choć może słowo „zaludniony” jest nie dość precyzyjne, bo mieszkańcami Srebrnego Globu są nie tylko ludzie.

\section{MiesZKAŃCY KSIĘŻYCA}

- Chang'e

Historia rozpoczyna się od postaci mitycznego łucznika Hou Yi (Hòu Yì 后 㑭) i dziesięciu słońc, które także były dziećmi (synami) cesarza Juna i jego żony $^{6}$. Co dzień o świcie jedno ze słońc wyruszało na wędrówkę po niebie, noc spędzały pod ziemią. Aż pewnego dnia postanowiły zażartować sobie z ludzi i wyszły na niebo wszystkie na raz. Żar lał się wszystkim na głowy i trudno było egzystować w taki upał. Jedyną osobą zdolną do sprowadzenia deszczu była szamanka, ale stojąc w palących słońcach, zginęła. Wtedy cesarz poprosił o pomoc Hou Yi, który miał raczej przekonać słońca, żeby zeszły $\mathrm{z}$ firmamentu, tymczasem on zestrzelił dziewięć z nich. Cesarz rozgniewał się na Hou Yi za to, że zabił jego synów, zamiast z nimi pertraktować i skazał jego oraz jego żonę Chang'e (Cháng'é 嫦娥) na pozostanie na ziemi. Hou Yi, nie chcąc być skazanym na pójście po śmierci do świata podziemnego, wyruszył na górę Kunlun (Kūnlún Shān 昆仑山; siedziba nieśmiertelnych), do Królowej Matki Zachodu (Xīwángmǔ 西王母). Od niej dostał pigułkę na nieśmiertelność, która miał podzielić się z żoną. Chang'e dowiedziała się

\footnotetext{
${ }^{3}$ JaCQUes PIMPANeAu, Chiny. kultura $i$ tradycje, przeł. Irena Kałużyńska (Warszawa: Wydawnictwo Akademickie Dialog, 2001), 139.

${ }^{4}$ DAOBIN FU, „Zhōngguó de yuèliang jíqí yìshù de xiàngzhēng 中国的月亮及其艺术的象征, Sohu.com 搜狐, 11.11.2017, dostęp 25.03.2019, http://www.sohu.com a/203781849_488759.

${ }^{5}$ Pimpaneau, Chiny. kultura i tradycje, s. 139.

${ }^{6}$ Innej niż matka księżyców.
} 
jednak, że jeśli połknie sama całą pigułkę, to nie tylko osiagnie nieśmiertelność, ale dostanie się do nieba. Zażyła ją więc potajemnie i wbrew własnej woli poleciała na Księżyc ${ }^{7}$. Tym samym stała się pierwszą jego mieszkanką. Edwin C. Krupp natomiast podaje, że Chang'e (nazywana u niego Heng O) wybrała Księżyc świadomie, jako schronienie przed gniewem męża ${ }^{8}$ (występującego w tym wariancie opowieści pod imieniem Shen I).

Według innych źródeł istnieje wersja tej legendy, która uniewinnia Chang'e i zdejmuje $\mathrm{z}$ niej odium złodziejki i zdrajczyni męża. Łucznik Hou Yi, sprawny w swej dyscyplinie i sławny, miał uczniów, z których jeden - Pang Meng ${ }^{9}$ - pewnego dnia, pozorując chorobę, zwolnił się z ćwiczeń. Potem zakradł się do domu łucznika i zażądał od jego żony, by oddała mu pigułkę nieśmiertelności. Chang'e, nie chcąc utracić cennego medykamentu, połknęła go w ostatniej chwili. Na skutek tego stawała się coraz lżejsza i zaczęła się unosić coraz wyżej, nie mogąc już powrócić na ziemię. Zatrzymała się na Księżycu, ponieważ pozwalało jej to pozostać stosunkowo blisko Ziemi. Hou Yi bardzo tęsknił za żoną. Wołał jej imię i szukał jej wzrokiem na niebie, aż zauważył na Księżycu cień postaci. Wystawił do ogrodu stolik, położył na nim przysmaki i owoce i nie przestawał wpatrywać się w oblicze Luny, myśląc, jak połączyć się z ukochaną. Stąd wziął się zwyczaj patrzenia na Księżyc, praktykowany współcześnie podczas Święta Środka Jesieni (Zhōngqiūjié 中秋 节 $)^{10}$, które przypada piętnastego dnia ósmego miesiąca księżycowego.

Eberhard opisuje Chang'e jako ,wytworną damę przeglądającą się w lustrze trzymanym przez służebną". Na wizerunkach Chang'e towarzyszy jej często dwoje dzieci, które patrzą na zająca (tù 兔) ${ }^{11}$. Owe dzieci raczej nie są stałymi mieszkańcami Księżyca, nie wspominają bowiem o nich inne źródła, ale zając już tak.

- Zając/królik

Bywa nazywany nefrytowym/jadeitowym zającem/królikiem (yùtù 玉兔) lub księżycowym zającem (yuè tù 月兔) i ponoć do dzisiaj można go dostrzec na Srebrnym Globie. Miał powstać z otaczającej pigułkę nieśmiertel-

\footnotetext{
${ }^{7}$ Pimpaneau, Chiny. kultura $i$ tradycje, 137-138.

${ }^{8}$ EDwin C. KRUpP, Za horyzontem. Mity i legendy o Stońcu, Księżycu, gwiazdach i planetach, przeł. Robert M. Sadowski (Warszawa: Prószyński i S-ka SA, 2006), 101-103.

${ }^{9}$ Cytowane źródło nie podaje znaków, być może jest to Feng/Peng Meng (Féng/Péng Méng 逢蒙), który - według legend - zabił Hou Yi z zawiści o jego umiejętności strzeleckie.

${ }^{10}$ SANMU TANG, Obchodzimy chińskie święta. Zbiór opowiadań i przepisów kulinarnych, przeł. Jadwiga Smulko (Ożarów Mazowiecki: Wydawnictwo Olesiejuk, 2013), 61-63.

${ }^{11}$ EBERHARD, Symbole chińskie, 40.
} 
ności skorupki, którą Chang'e wypluła, lądując i zderzając się z powierzchnią Księżyca ${ }^{12}$. Przedstawia się go z moździerzem i tłuczkiem (o kształcie fallusa), a narzędzia te są mu potrzebne do ścierania/tłuczenia kory drzewa cynamonowego (gui 桂, o nim później). Specyfik ma zapewniać nieśmiertelność, a sam zając symbolizuje długowieczność. Zając jest jednym ze zwierząt towarzyszących wizerunkom Xiwangmu, co ma dowodzić, że pojawiał się już w najstarszych chińskich legendach ${ }^{13}$. Jedna z nich mówi o tym, jak trzech mędrców, przybrawszy postacie umierających z głodu, starych żebraków, na swej drodze spotkało lisa, małpę i zająca. Trzej mędrcy, upostaciowani na żebraków, poprosili zwierzęta o pożywienie. Lis i małpa natychmiast podzielili się z nimi tym, co mieli, ale biedny zając sam był głodny i nie miał czym się pożywić ani poczęstować żebraków. Zdecydowany ocalić tych trzech od śmierci głodowej, rzucił się w ogień, składając siebie w ofierze. Mędrcy byli tak poruszeni zachowaniem zająca, że za pomocą swojej magicznej mocy ożywili go i dali mu wieczne życie. Potem został wysłany do Księżycowego Pałacu, by towarzyszyć Cheng'e ${ }^{14}$.

- Ropucha/żaba

Podobnie „starym” zwierzęciem mitycznym jest ropucha (háma 蛤蟆, chánchú 蟾蜍)/żaba ( $w \bar{a}$ 蛙), którą - obok zająca — odnajdziemy wśród towarzyszy Królowej Matki Zachodu oraz na Księżycu. Bywa ona utożsamiana z Chang'e, kolejna bowiem wersja legendy głosi, że żonie Hou Yi udało się uzyskać nieśmiertelność, ale pod postacią trójnogiej ropuchy ${ }^{15}$, w którą przemieniła się, wypijając pierwszy łyk księżycowej rosy. Prawdopodobnie wraca do ludzkiej postaci („,pięknieje”) każdego piętnastego dnia miesiąca, kiedy odwiedza ją mąż $\dot{z}^{16}$.

Związek trójnogiej ropuchy z nieśmiertelnością potwierdzony zostaje również poprzez fakt, iż stała się ona atrybutem jednego z Ośmiorga Nieśmiertelnych (bāxiān 八仙) — Zhang Guolao (Zhāng Guǒlăo 张果老) ${ }^{17}$ oraz była kompanem podróży innego nieśmiertelnego - Liuhai Xiana (Liúhăi $X i a ̄ n$ 刘海仙/Liú Hăichán 刘海蟾/Hăichánzǐ 海蟾子). W trakcie ich

\footnotetext{
${ }^{12}$ KRUPP, Za horyzontem, 101.

${ }^{13}$ Derek Walters, Mitologia Chin, przeł. Wisława Szkudlarczyk (Poznań: Dom Wydawniczy ReBIS, 1996), 113; EBERHARD, Symbole chińskie, 40, 297.

${ }^{14}$ Sabrina Liao, Chinese Astrology: Ancient Secrets for Modern Life (New York: Hachette Book Group, 2000), 68 (numer strony według wydania w wersji PDF — https://www.hachette bookgroup.com/titles/sabrina-liao/chinese-astrology/9780759520486/).

${ }^{15}$ WALters, Mitologia Chin, 149.

${ }^{16}$ Krupp, Za horyzontem, 102.

${ }^{17}$ WaLters, Mitologia Chin, 132.
} 
wspólnej wędrówki często uciekała do studni i Liuhai musiał ją wywabiać za pomocą przynęty w postaci złotych monet. $\mathrm{Z}$ tego powodu Liuhai Xian uważany był za boga bogactwa ${ }^{18}$.

Zwierzę to jest jednocześnie symbolem Księżyca oraz nieosiągalnego marzenia, ponieważ — według podań — podczas zaćmienia trójnoga ropucha zjada Księżyc ${ }^{19}$. Spośród wierzeń dotyczących żaby wartym wspomnienia jest to, że podobno jedna $\mathrm{z}$ dusz ${ }^{20}$ człowieka, o nazwie hun (hún 魂), ma kształt tego płaza, a w Korei sen o żabie przynosi nadzieję na narodziny syna ${ }^{21}$.

- Wu Gang

Czwartym i zdaje się nie ostatnim ze znanych starożytnym Chińczykom mieszkańców Księżyca jest znów człowiek, chiński Syzyf, mężczyzna zwany Wu Gang (Wú Gāng 吴刚). Oto przytoczona w całości jedna z wersji legendy o Wu, która sugeruje, że również trzech jego synów stało się księżycowymi obywatelami: „Wu Gang, zwany także Wu Quan (Wú Quán 吴权), pochodzi z Xihe (Xīhé 西河). Wnuk Płomiennego Cesarza (Yándì 炎帝), Bo Ling (Bó Líng 伯陵), korzystając z trzyletniej nieobecności Wu Ganga, który zgłębiał dao (dào 道) nieśmiertelności, miał romans $\mathrm{z}$ jego żoną i spłodził z nią troje dzieci. Wu Gang, w napadzie złości, zabił Bo Linga, czym wywołał gniew Płomiennego Cesarza. Za karę, Yandi zesłał Wu Ganga na chłodny, martwy Księżyc i rozkazał mu ścinać nieumierające drzewo - księżycowy cynamonowiec. Drzewo to było wysokie na pięćset $z h a n g^{22}$. Choć Wu Gang je ścinał, stale odrastało, a Yandi wykorzystał tę wieczną pracę bez odpoczynku jako karę dla zabójcy. Żona Wu Ganga miała wyrzuty sumienia, nakazała więc swoim trzem synom polecieć na Księżyc i towarzyszyć mu. Jeden z nich zmienił się w ropuchę, drugi — w zająca, a trzeci - w węża"23.

Inny wariant tej opowieści mówi, że Wu Gang był strażnikiem Południowych Wrót Niebiańskich, ale zaczął zaniedbywać swoje obowiązki, ponieważ romansował z Chang'e. Gdy się o tym dowiedział Nefrytowy/Jadeitowy Cesarz (Yùhuáng 玉皇 lub Yù Dì 玉帝 ${ }^{24}$ ), zirytował się i za karę zesłał Wu na

\footnotetext{
${ }^{18}$ WALters, Mitologia Chin, 95-96.

${ }^{19}$ EBERHARD, Symbole chińskie, 220.

${ }^{20}$ Zgodnie z tradycją człowiek w Chinach miał wiele dusz, które dzieliły się na dwie kategorie: dusze materialne (cielesne) - pò 魄 i gul̆ 鬼 oraz dusze niematerialne - hún 魂 i shén 神.

${ }^{21}$ EBERHARD, Symbole chińskie, 308-309.

${ }^{22}$ Zhàng 丈 to około 3,3 m, czyli 500 zhang to około $16,5 \mathrm{~km}$.

23 „Bùtóng bănběn Wú Gāng fá guì de chuánshuō gùshì”, Sohu.com 搜狐, 25.01.2018, dostęp 24.05.2018, http://www.sohu.com/a/218795462_100058695.

${ }^{24}$ Oba imiona są prawdopodobnie skrótem od całego tytułu: Yùhuáng Dàdì 玉皇大帝 Jadeitowy/Nefrytowy Cesarz Niebios, bóstwo z panteonu taoistycznego.
} 
Księżyc, by tam ścinał ogromne drzewo - księżycowy cynamonowiec. Dopiero gdy drzewo zostanie ścięte z korzeniami, Wu Gang może powrócić do Wrót i spotkać się z boginią. Wu Gang ciął i ciął, co najmniej pół roku, i spodziewał się, że lada moment skończy, ale wtedy Nefrytowy Cesarz posłał w pobliże drzewa kruka, który przeleciał ze świstem i zabrał z drzewa kurtkę, zawieszoną tam uprzednio przez Wu Ganga. Ten od razu odłożył topór i zaczął ścigać ptaka. Kiedy odzyskał odzienie, wrócił pod drzewo i spojrzał, a tam wszystkie gałęzie i liście, które dotychczas ściął, odrosły. Od tej pory, kiedy tylko Wu Gang jest bliski końca swojej pracy, na drzewie siada kruk i zaczyna krakać. Wu Gang musi przerwać pracę i spojrzeć na niego, a wtedy z drzewa ponownie wyrastają gałęzie i liście. W ten sposób mija rok za rokiem, a Wu Gang nie może całkowicie ściąć księżycowego cynamonowca. Tylko szesnastego dnia ósmego miesiąca zdarza się, że gałęzie i liście cynamonowca opadają na ziemię, spadając do zagrody najbardziej pracowitej rodziny, która już nigdy nie zazna biedy ${ }^{25}$.

W kolejnej odmianie tego mitu kwiat cynamonowca staje się antidotum na zarazę, a Wu Gang dzielnym młodzieńcem, który pragnie uratować swoją matkę. Chciałby zabrać cynamonowiec do świata ludzi, by wszystkich ochronić przed chorobą. Ponieważ swym wtargnięciem do Pałacu księżycowego naraża się jednak bogom, zostaje ukarany i znów podejmuje nierówną walkę z drzewem. Nefrytowy Cesarz w magiczny sposób sprawił, że wszystko to, co Wu Gang odciął, odrastało ponownie ${ }^{26}$.

Legendy mówią też o tym, że cykl ścinania drzewa jest dobowy: Wu Gang próbuje pokonać drzewo każdej nocy, a ono odrasta w ciągu dnia ${ }^{27}$.

Wreszcie istnieje także wersja mówiąca o tym, że na Księżycu przebywa chłopiec ukarany za chciwość. Ponieważ wcześniej widział, że jego sąsiad za udzielenie pomocy rannemu ptakowi otrzymał magiczne ziarno, z którego wyrosła dynia o owocach pełnych złota i srebra, celowo zranił i wyleczył innego ptaka. $Z$ ofiarowanego mu ziarna nie wyrosła jednak dynia niosąca drogocenne kruszce. $Z$ owocu wyszedł staruszek i przedstawił chłopcu „rachunek z wielkim długiem". Następnie dyniową windą zabrał go na Księżyc, gdzie bogini postawiła mu ultimatum: wróci do domu, jeśli zetnie rosnące przed jej pałacem drzewo. Było to cynamonowe drzewo nieśmiertelności, na którym natychmiast zamykały się wszystkie zadawane toporem rany, a chłopiec był skazany na wieczne wygnanie ${ }^{28}$.

\footnotetext{
${ }^{25}$ „Bùtóng bănběn Wú Gāng fá guì de chuánshuō gùshì”.

${ }^{26}$ Ibid.

${ }^{27}$ EBERHARD, Symbole chińskie, 55.

${ }^{28}$ KRUPP, Za horyzontem, 106-107.
} 


\section{OBIEKTY NA KSIĘŻYCU}

- Drzewo cynamonowe

Historia Wu Ganga prowadzi nas do kolejnego lokatora, jaki znajduje się na Księżycu, tym razem przedstawiciela flory, a mianowicie do drzewa cynamonowego ${ }^{29}$. Rośnie ono na dziedzińcu Pałacu księżycowego (yuègōng 月宫). „Drzewo kasjowe rośnie tak bujnie, że z czasem zasłoniłoby cały blask Księżyca. Dlatego musi być ono ścinane co tysiąc lat" ${ }^{\prime 0}$. Jego kwiaty mają przepiękny zapach, któremu nie można się oprzeć, a z którym związane jest dość zabawne skojarzenie: „złamać gałąź cynamonu” oznacza „zdać egzaminy państwowe" - podobno kiedy kandydat ukończy je z sukcesem, rozsiewa wokół przyjemną woń. Według tradycyjnego kalendarza drzewo cynamonowe kwitnie w ósmym miesiącu, jego kwiaty zatem są uznawane za kwiaty jesienne ${ }^{31}$. Jego liście są wiecznie zielone ${ }^{32}$.

- Pałac rozległego zimna ${ }^{33}$

Na Księżycu odnajdziemy także imponującą budowlę, którą dla ukontentowania Chang'e zbudował Han Zhuo (Hán Zhuó 寒浞) - Pałac rozległego zimna (guănghángōng 广寒宫). Inne jego nazwy to Pałac ropuszy ${ }^{34}$ (chángōng 蟾宫), co ma oczywiście związek z postacią Chang'e, lub Pałac księżycowy (yuègōng 月宫) ${ }^{35}$. Dlaczego tam właśnie zamieszkała Chang'e? Jedna z wersji legendy mówi, że została tam umieszczona za karę przez Nefrytowego Cesarza, ponieważ ukradkiem sama zażyła pigułkę, która była przeznaczona także dla jej męża. Jak tylko doleciała do Nieba, została uwięziona w samotności w Pałacu rozległego zimna. Choć budowla była ogromna, nie było w niej żadnego człowieka, z którym Chang’e mogłaby zamienić słowo (zadaniem Wu Ganga było jedynie ścięcie drzewa, nie mógł się odzywać).

\footnotetext{
${ }^{29}$ Lub też — jak podają źródła — kasjowego. Według jednak Encyklopedii PWN nazwę kasja stosuje się m.in. na określenie przyprawy - kory cynamonowca (wonnego). „Kasja”, w: Encyklopedia PWN, PWN, dostęp 9.09.2018, https://encyklopedia.pwn.pl/haslo/kasja;3920895.html.

${ }^{30}$ Baśń o księżycowej wróżce według tłumaczenia Richarda Wilhelma; cytat za: EBERHARD, Symbole chińskie, 55.

${ }^{31}$ EBERHARD, Symbole chińskie, 55.

${ }^{32}$ KRUPP, Za horyzontem, 100.

${ }^{33}$ Taką nazwę podaje Eberhard pod hasłem „Chang'e” (Za horyzontem, 40) na s. 85 budowla ta pojawia się jako Pałac dalekiego chłodu. Krupp (Za horyzontem, 107) tłumaczy tę nazwę jako Pałac Niezmierzonego Zimna.

${ }^{34}$ Według słownika chán (chú) 蟾(蜍) oznacza zarówno ropuchę, jak i Księżyc.

${ }^{35}$ ZHANGXIU (red.), „Guănghángōng de láilì. Cháng'é bènyuè y̌̌hòu wèishénme zhùzài guănghángōng”. Lishǐ qùwén 历史趣闻 2015, dostęp 10.09.2018. http://www.lishiquwen.com/news/ 37.html.
} 
Yu Di chciał, by Chang'e dogłębnie posmakowała goryczy samotności i chłodu i w ten sposób odpokutowała swój grzech ${ }^{36}$.

Mitycznym dowodem istnienia na Księżycu takiego pałacu może być wycieczka cesarza Xuanzonga (Táng Xuánzōng 唐玄宗, 685-762) ${ }^{37}$. Ponoć w podróży tej pomógł mu i towarzyszył czarodziej. Jak zapisał Liu Zongyuan (Liǔ Zōngyuán 柳宗元, 773-819) ${ }^{38}$, ujrzawszy na miejscu ogromną rezydencję, cesarz określił ją jako „rozległą, zimną, cichą i pustą” ${ }^{39}$. Eberhard dodaje, że ,zobaczyli [tam] pałace i żyjące w nich piękne boginki ${ }^{40}$. Xuanzong nauczył się od nich pozaziemskiej melodii" ${ }^{41}$. Panny wywarły na władcy tak duże wrażenie, że „Cesarz musiał ciaggle wracać myślami do księżycowych boginek, wspominał, jak tańczyły fruwając na wietrze z powiewającymi rękawami i pelerynami. Zaczął więc komponować i stworzył melodię do tekstu Strój z chmur i suknia z piór" ${ }^{\prime 2}$.

Piękną ilustracją połączenia rozmaitych wierzeń dotyczących Księżyca jest rytuał ludu Tanka, mieszkającego na łodziach i żyjącego w południowych Chinach, odprawiany na cześć świeżo zaślubionej pary. Piętnastego dnia ósmego miesiąca (według kalendarza księżycowego) przy drzwiach sypialni nowożeńców stawia się drzewo cynamonowe, pod którym znajdują się ropucha i zając. Małżeńskie łoże jest zasłonięte parawanem, a przed nim stoją świece. Tak przygotowaną łożnicę nazywa się „pałacem ropuchy”. Jedna ze starszych kobiet wciela się w postać Królowej Matki Zachodu i prowadzi ceremonię. Na otwartej platformie na przodzie łodzi umieszcza się pokarmy i napoje, które mają przynieść szczęście: orzechy ziemne, ziarna dyni, ciasto zawierające cynamon, herbatę, wino. W dniu ponownych zaślubin zbierają się krewni i powinowaci żony i męża, a młoda para, ponownie w weselnych strojach, ustawia się w promieniach Księżyca. „Potem udają się do „księżycowego pałacu” (pokoju nowożeńców) i zatrzymują przed „bramą księżycowej hali” (przed łożem)". Kobieta grająca rolę Xiwangmu żegna ich słowami zachęty, para obejmuje się, całuje i jest odprowadzana do „pałacu

\footnotetext{
${ }^{36}$ ZHANGXIU (red.), „Guănghángōng de láili”.

${ }^{37}$ Jeden $z$ władców z dynastii Tang, żył w latach 685-762, panował w latach 712-756.

${ }^{38}$ Poeta żyjący w czasach dynastii Tang. Cytat pochodzi z dzieła „Zapiski z Longcheng”, traktujacego o tym, jak Minghuang udał się w senną podróż do Pałacu rozległego zimna (Lóngchéng lù. Mínghuáng mèngyóu guănghángōng 《龙城录。明皇梦游广寒宫》). Minghuang to pośmiertne imię cesarza Tang Xuanzonga.

${ }^{39}$ EBERHARD, Symbole chińskie, 119; , „guăng hán gōng 广寒宫”, w: Hàn wénxué wăng | Hànyǔ cídiăn 汉文学网|汉语词典, dostęp 11.09.2018, http://cd.hwxnet.com/view/ogofofkhme hekagj. html.

${ }^{40}$ Boginkami (xiānnü̈ 仙女) są m.in. Xiwangmu, Chang'e, Nüwa.

${ }^{41}$ EBERHARD, Symbole chińskie, 119.

${ }^{42}$ Ibid., 27.
} 
ropuchy". W taki sposób czczono niegdyś Księżyc w ten sam dzień na obszarze całego kraju ${ }^{43}$.

\section{FAKTY}

W chińskiej kulturze najbardziej elementarnym jest związek Księżyca z matką i kobietą. Jako dowód Daobin Fu przywołuje klasyczne teksty, takie jak „Księga rytuałów” (Lijì 《礼记》) czy „Kronika Wiosen i Jesieni” pana Lü (Lüshì chünqiū 《吕氏春秋》). Według niego zależność ta powstała w odległych czasach, kiedy praprzodkowie Chińczyków byli wyznawcami kultu płodności, który przejawiał się głównie w czczeniu kobiety, a dominującym w społeczeństwie systemem był matriarchat. Zdaniem uczonego starożytni długo nie pojmowali roli mężczyzny w procesie rozmnażania, uznając, że dawanie nowego życia jest zasługą wyłącznie kobiety. Stąd w chińskich mitach pojawia się spora grupa matek-dziewic, a wielu świętych i mędrców nie ma ojca ${ }^{44}$.

O wielowiekowym związku Księżyca z kobietą świadczyć mają także malowidła nagrobne, odkryte w czasach dynastii Han (Hàncháo 汉朝, 206 p.n.e. -220 n.e.), na których przedstawiano Nüwę trzymającą w ręku właśnie Księżyc. Wiele źródeł pisanych wspomina też o wpływie tego satelity na ciało kobiet. Na przykład Kronika południowych dynastii Song (Sòngsh $\bar{u}$ 《宋书》) opisuje Fudu (Fúd̄u 扶都), konkubinę króla Zhuguia (Zhŭguǐ 主癸) z dynastii Xia (Xiàcháo 夏朝, 2070-1600 p.n.e.), która zaszła w ciążę po tym, jak ujrzała biały obłok zasłaniający oblicze Księżyca. Li Qin (Ľ̀ Qīn 李亲), bohaterka Kroniki dynastii Han (Hànshu 《汉书》), będąc już brzemienna, we śnie widziała, jak na jej pierś pada blask Księżyca i dzięki temu jej córka wyrosła na cnotliwą pannę, znającą obowiązki przykładnej żony (według tradycyjnej, konfucjańskiej etyki ${ }^{45}$.

Także według Wu Tianminga jednym z najważniejszych zagadnień, jakie nurtowało badaczy mitów związanych z Księżycem, był jego związek z żabą, a następnie z kobietą i kobiecym łonem. Ustalili oni, że wzór żaby (ropuchy) jest drugim po rybie wzorem, który pojawił się na artefaktach pozostawionych przez kulturę prymitywnego, matriarchalnego społeczeństwa chińskiego. Chociaż jest młodszy niż ryba, to był o wiele bardziej rozpow-

\footnotetext{
${ }^{43}$ EBERHARD, Symbole chińskie, 221.

${ }^{44}$ FU. „Zhōngguó de yuèliang”.

${ }^{45}$ Ibid.
} 
szechniony i współcześnie na sporym obszarze środkowo-zachodnich Chin sukcesywnie odkrywane są przedmioty świadczące o tym, że wśród wielu pierwotnych ludów istniały mity o kulcie bóstwa żaby ${ }^{46}$.

Pewne cechy budowy i zachowania żab sprawiły, że dla starożytnych stały się one symbolem kobiecego łona: po pierwsze brzuch żaby, podobnie jak brzuch ciężarnej kobiety, jest idealnie okrągły i rozdęty; po drugie płazy te charakteryzują się bardzo dużą płodnością. Wystarczy jedna deszczowa noc, by wydały na świat niezliczoną liczbę potomstwa, a to była umiejętność, którą pierwotni podziwiali i której zazdrościlii ${ }^{47}$.

Kolejnym wzorem, który możemy zaobserwować w prymitywnej sztuce chińskiej był wzór ciała człowieka i żaby połączonych razem, co może być dowodem na to, że w późnym społeczeństwie matriarchalnym żaba nie tylko nosiła symboliczne znaczenie kobiecych genitaliów, ale także rozwinęła się w symbol kobiety. Ponadto wymowa słowa $w \bar{a}$ 蛙 ('żaba') na drodze ewolucji fonetycznej stała się tożsama z artykulacją sylaby $w \bar{a}$ 娲 ze słowa $N \ddot{u} w \bar{a}$ 女娲 ${ }^{48}$.

Jeśli chodzi o fonetyczne związki Księżyca, człowieka i żaby, to według $\mathrm{Fu}$ jest to nie tylko współbrzmienie trzech sylab 'wa' (trzecią jest wá 娃 oznaczające 'dziecko' lub 'lalkę'). Podaje on, że niegdyś słowo 'ropucha' zapisywano znakiem min 黾, a znak oznaczający 'kobietę w ciąży' był połączeniem elementów 'kobieta': nü 女 i 'ropucha' min 黾. Natomiast tradycyjna medycyna chińska do dziś określa kobiecy srom słowami „usta żaby/ ropuchy" (háma kǒu 蛤蟆口/wā kǒu 蛙口/wá kǒu 娃口) $)^{49}$.

Kolejnym elementem układanki było skonstatowanie przez starożytnych, że cykl przejścia Księżyca od nowiu do pełni i od pełni do nowiu wynosi dwadzieścia osiem dni, co zgadza się idealnie z rytmem cyklu miesięcznego u kobiety ${ }^{50}$. Także kolejne fazy Księżyca, od jego braku do krągłości i odwrotnie, są identyczne ze zmianą kształtu brzucha kobiety: kiedy jest w ciąży z płaskiego robi się okragły, a później odwrotnie, wraca do oryginalnej formy. $\mathrm{Z}$ tego powodu ludzie pierwotni, czczący bóstwo żabę i bóstwo Księżyc, wyobrażali sobie, że na Księżycu egzystuje żaba, odpowiedzialna za roz-

\footnotetext{
${ }^{46}$ Tianming Wu. The Study on Chinese Myths (Beijing: Central Compilation \& Translation Press, 2003), 246.

${ }^{47}$ Ibid.

${ }^{48}$ Ibid.

${ }^{49}$ Fu. ,Zhōngguó de yuèliang”.

${ }^{50}$ Współcześni Chińczycy wciąż określają miesiączkę takimi słowami jak yuè shuı̌ 月水 ('księżycowa woda'), yuèxìn 月信 ('księżycowy list'?) czy yuèjīng 月经 (w całości oznacza miesiączkę, ale jīng 经 oznacza także 'klasyk', 'świętą księgę', 'pismo').
} 
mnażanie. Ponadto słowo chán 蟾 ${ }^{51}$ było niegdyś homofonem słowa cháng 嫦 (z imienia Cháng'é), natomiast chú 蜍 ${ }^{52} \mathrm{w}$ archaicznym języku chińskim wymawiało się tak samo jak tù 兔 ('królik'), dlatego później dokwaterowano na Księżyc także boginię Chang'e i jadeitowego królika"

Warto dodać, że według specjalistów Chang'e i Nüwa to ta sama osoba. Jak pisze Fu, cytując He Xina, badacza chińskiej literatury klasycznej, metamorfoza jednej bogini w druga jest tylko kwestią zmian w fonetyce języka chińskiego. Natomiast przejście od wielkiej bogini-kreatorki do samotnej bogini mieszkającej na Księżycu ma swoje źródło w zmianie sposobu postrzegania świat przez starożytnych, wyborze innego obiektu kultu - mężczyzny - oraz w upadku matriarchalnego systemu wierzen ${ }^{54}$.

Wu uważa, że powiązanie źródeł kultu żaby i Księżyca tylko z aspektem płodności jest stronnicze i nie daje pełnego obrazu badań. Sugeruje, by wziąć pod uwagę również ich związek z dwoma aspektami długowieczności (chángshēng 长生): śmiercią i zmartwychwstaniem (sì ér fùshēng 死而复生) pojedynczego człowieka oraz nieśmiertelnością (chángshēng-bùsǐ 长生不死) całej rasy. Analogia między kształtem i płodnością żab i kobiet to nie jedyny powód, dla którego te płazy były czczone. Bóstwo żaba włada także dwojakiego rodzaju tajemniczą siłą umierania i zmartwychwstawania:

- Czas, w którym kobieta jest płodna i może urodzić dzieci, jest przez naturę ograniczony pierwszą i ostatnią owulacją. Żaby mogą wydać na świat nieograniczoną liczbę dzieci, nieskończenie wiele razy, każdego roku, kiedy tylko na świat powróci wiosna. Gdyby — zgodnie z sugestią Wu - te okresy płodności nazwać „,̇yciem”, a okres bezpłodności „,́́miercią" i gdyby te kolejne okresy utraty i powrotu płodności nazwać „,́́miercią i zmartwychwstaniem", to właśnie byłaby główna, wspólna dla praprzodków idea przenikająca religijne mity, nieobca również kolejnym pokoleniom $^{55}$.

- Bóstwo żaba samo w sobie ma magiczną życiową siłę „umierania i zmartwychwstawania". Żaby mają zwyczaj zapadać w zimowy sen i to właśnie sprawiło, że pierwotni ludzie, nieświadomi pewnych procesów zachodzących w naturze, przypisali im umiejętność zmartwychwstawania. Żyjący

\footnotetext{
51 'Księżyc', 'pręgowana ropucha'.

52 Także 'ropucha'.

${ }^{53}$ Fraza 'jadeitowy królik' słownikowo także znaczy 'Księżyc'. Wu, The Study on Chinese Myths, 246.

${ }^{54} \mathrm{FU}$, ,Zhōngguó de yuèliang”.

${ }^{55}$ Wu, The Study on Chinese Myths, 247-248.
} 
w czasach dynastii Jin (Jincháo 晋朝) ${ }^{56}$ Ge Hong (Gě Hóng 葛洪, 283-343) ${ }^{57}$ w rozdziale „Rozwiązywanie problemów” (Shizhi 《释滞》) w ,[Księdze] mistrza, który pojął prostotę” (Bàopǔž 《抱朴子》) napisał: „Nüwa wyszła na ziemię" ${ }^{58}$. Fragment ten ma oznaczać, że bóstwo żaba, po zimowym śnie, wiosną i latem znów przebywało na ziemi, oraz sugerować, że bóstwa-przodkowie pochowani po śmierci w ziemi, moga powrócić jak ona. Zwierzęta takie jak żaba, wąż, świstak i inne, które maja zwyczaj hibernowania na zimę, jawiły się ludziom jako posiadające szczególną moc i często były obiektami kultu ${ }^{59}$.

Podobnie rzecz się ma z Księżycem - także posiada moc chudnięcia i zaokrąglania się, umierania i zmartwychwstawania. Wszystkie ludy pierwotne czciły Słońce, Księżyc, gwiazdy i wiele innych zjawisk naturalnych; wschody i zachody Księżyca, pełnia i nów musiały naturalnie przyciągnąć ich zainteresowanie, a poprzez długotrwałą obserwację udało im się stwierdzić, że w tym procesie jest reguła. W odniesieniu do Słońca wschód symbolizował życie, zachód oznaczał śmierć, a ponowny wschód - zmartwychwstanie. $Z$ tego możemy wnioskować, że tak samo pełnię Księżyca starożytni uważali za życie, nów - za śmierć, a przemianę zachodzącą pomiędzy nowiem a pełnią — za śmierć i zmartwychwstanie ${ }^{60}$. Wynika $\mathrm{z}$ tego, że bóstwo Księżyca i bóstwo żaba, albo może bóstwo Księżyca tak jak bóstwo żaba, mają siłę umierania i zmartwychwstawania, a zatem mogą sprawić, że przodkowie powstaną z martwych. Mity ludów całego świata zawierają taki motyw, że ich przodkinie i przodkowie mogą zmartwychwstać. W Chinach reprezentantami takich opowieści mogą być: mit o Żółtym Cesarzu (Huángdì 黄帝) ${ }^{61}$, który wstąpił do nieba, lecąc na smoku; o Chang'e, która wzleciała na Księżyc i stała się nieśmiertelną; o cesarzu Di Ku (Dì Kù 帝営) ${ }^{62}$, który wiosną i latem dosiadał smoka. Oni wszyscy nie tylko byli długowieczni, ale $\mathrm{w}$ razie śmierci potrafili zmartwychwstać, ponadto mieli magiczną moc zapewnienia swojemu ludowi takich przymiotów ${ }^{63}$.

Jeśli chodzi o zająca, to Yin Rongfang twierdzi, że ogniwem łączącym go z kobieta jest jego nieograniczona niczym płodność, a z Księżycem to, że

\footnotetext{
${ }^{56}$ Dynastia panująca w latach $265-420$.

${ }^{57}$ Taoistyczny uczony i lekarz.

58 „Nü̈wā di chū 女娲地出”.

${ }^{59}$ Wu, The Study on Chinese Myths, 249.

${ }^{60}$ Ibid., 250-251.

${ }^{61}$ Legendarny władca panujący w latach 2697-2597.

62 Jeden z pięciu legendarnych cesarzy, wnuk Huangdi, panował w latach 2412-2343.

${ }^{63} \mathrm{Wu}$, The Study on Chinese Myths, 251.
} 
młode rodzą się około dwadzieścia dziewięć dni po zapłodnieniu. Samica zaraz po porodzie jest gotowa do kolejnej kopulacji, a zatem mogłaby zachodzić w ciąże i rodzić w miesięcznych, księżycowych cyklach. Poród $\mathrm{z}$ reguły odbywa się wieczorem, czyli w czasie, kiedy wschodzi Księżyc ${ }^{64}$.

- Siódemka

Związek cyfry siedem z Księżycem jest chyba najmniej tajemniczy ze wszystkich omawianych tu zagadnień. Nietrudno zauważyć, że Księżyc zmienia swój kształt co siedem dni. Dostrzegli to również praprzodkowie Hanów, a spośród czterech siedmiodniowych okresów wybrali dwa, w czasie których składali ofiary bóstwu. Była to „pierwsza siódemka” (yīqi -七) i „druga siódemka” (èrqī二七), czyli czas, kiedy Księżyc „rósł”. Mógł to być także siódmy dzień siódmego miesiąca, czyli qiqi (qīq $\bar{l}$ 七七). „Pierwsza siódemka” symbolizowała koniec życia i zmartwychwstanie, „druga siódemka” to śmierć i zmartwychwstanie płodności, żyzności, urodzajności. Wybrali ten właśnie czas, ponieważ mieli nadzieję „pożyczyć” od Księżyca jego magiczną życiową moc ${ }^{65}$.

\section{JESZCZE O ŚWIĘTACH}

Święta, które tradycyjny chiński kalendarz łączy z Księżycem, to przede wszystkim:

- Święto Środka Jesieni

Nazywane inaczej Świętem Ósmego Miesiąca (Bāyuèjié 八月节), obchodzone piętnastego dnia ósmego miesiąca, którego historię została krótko zarysowana w części przedstawiającej sylwetkę Chang' ${ }^{66}$. Tradycyjnie w tym okresie jada się ciasteczka księżycowe (yuèbǐng 月饼), które współcześnie przybierają różne kształty, ale pierwotnie były okragłe, co miało symbolizować „połączenie rodzin” (yuán 圆 — 'okragły’; tuányuán 团圆 — 'ponownie się spotkać, połączyć'). Wszyscy domownicy powinni razem zajadać się tymi przysmakami i podziwiać oblicze Księżyca. Jeśli ktoś w dniu święta nie może być w rodzinnym domu, powinien tego wieczoru obserwować Księżyc w miejscu, w którym się znajduje, i myśleć o swoich bliskich.

Zapiski historyczne mówią, że tradycja spożywania ciasteczek ma związek z pewnymi wydarzeniami, które miały miejsce u schyłku panowania dynastii

\footnotetext{
${ }^{64} \mathrm{FU}$, ,Zhōngguó de yuèliang”.

${ }^{65}$ Wu, The Study on Chinese Myths, 261, 265, 283.

${ }^{66}$ Cf. p. 1: Mieszkańcy Księżyca. Chang'e.
} 
Yuan (Yuáncháo 元朝, 1279-1368) ${ }^{67}$. Zhu Yuanzhang (Zhū Yuánzhāng 朱元 璋, 1328-1398) ${ }^{68}$, przywódca powstania przeciwko panującej tyranii, zaplanował wywołać rebelię właśnie piętnastego dnia ósmego miesiąca, a ciastek użył jako środka komunikacji, wkładając do środka wiadomości ${ }^{69}$.

- Święto Podwójnej Siódemki (Qīxījié 七夕节)

Krócej zwane Qixi lub też Qiqiao (Qíqiăo 乞巧), nosi także miano „chińskich walentynek”. Jest ono związane z legendą o wielkiej miłości Tkaczki i Pastucha, dramatycznym rozdzieleniem kochanków i ich corocznymi spotkaniami w siódmym dniu siódmego miesiąca, kiedy właśnie obchodzi się to święto. Historia ma także wymiar kosmiczny, Tkaczka bowiem to gwiazda Wega, Pasterz to inaczej Altair, a granicę, która ich rozdziela, stanowi Droga Mleczna. Raz do roku spotykają się ponad nią, wstępując na most utworzony przez sroki (quèqiáo 鹊桥).

W Chinach jest to właściwie święto kobiet, które w tym dniu składają Tkaczce wykonane $\mathrm{z}$ papieru ofiary. $\mathrm{Z}$ reguły proszą ją, by obdarzyła je umiejętnościami hafciarskimi oraz by dała im dobrych mężów ${ }^{70}$.

Zauważalne jest $\mathrm{z}$ pewnością to, że opisując drugie święto, nie wspomniano ani słowem o Księżycu. Tymczasem na wizerunkach związanych ze Świętem Podwójnej Siódemki bardzo często przedstawia się parę zakochanych na tle Księżyca w pełni. Jaki zatem mają związek? Tianming Wu wyjaśnia to w ten sposób: mniej więcej w czasach dynastii Yin (Yīn 殷, 17661045 p.n.e. $)^{71}$ na Równiny Centralne wkroczyły mity o Królowej Matce Zachodu i najpóźniej w czasach Zachodniej dyn. Han (Xī Hàn 西汉, 206 p.n.e. - 9 n.e.) zmieszały się one z mitami o Księżycu związanymi ze świętem Qixi. Ponieważ oba bóstwa - zamieszkująca Księżyc Chang’e i Królowa Matka Zachodu - są kobietami, a w starożytności coraz bardziej rosło znaczenie umiejętności przędzenia i tkania, z mitów o Księżycu wyprowadzono mit o Tkaczce, a fakt, że starożytni składali ofiary ku czci Księżyca podczas Święta Podwójnej Siódemki jest echem tych wierzeń ${ }^{72}$.

\footnotetext{
${ }^{67}$ Dynastia panująca w latach $1271-1368$.

${ }^{68}$ Później pierwszy cesarz dynastii Ming (Míngcháo 明朝, 1368-1644), przybrał imię Hongwu (Hóngwǔ 洪武). Żył w latach 1328-1398, panował w latach 1386-1398.

${ }^{69}$ Y ING DA 笪颖. „Zhōngqiū chī yuèbǐng de lálì 中秋吃月饼的来历”. People.cn 人民网, dostęp 11.09.2018, http://history.people.com.cn/n/2014/0905/c388792-25610906.html.

${ }^{70}$ Pimpaneau, Chiny. kultura i tradycje, 151.

${ }^{71}$ Inaczej Shang (Shāngcháo 商朝), pierwsza dynastia, której panowanie w Chinach zostało udokumentowane.

${ }^{72}$ Wu, The Study on Chinese Myths, 247.
} 
Kolejna warstwa symboli, które kojarzone są z Księżycem, jest efektem opisanych powyżej wierzeń. Kobieca uroda sprawiła, że satelita stał się alegorią piękna, a następnie miłości. Ponieważ Księżyc ma odzwierciedlać kobiecą melancholię, smutek i troskę, jest także kojarzony z utratą nadziei, a w następstwie z samotnością. Symbolizuje też harmonijny, niezmącony umysł uczonego oraz swobodny, ale jednocześnie wykwintny jego styl i postawę. To Księżyc sprawił, że chińscy filozofowie zaczęli kontemplować takie zagadnienia jak wieczność, ludzka egzystencja i duchowość oraz szukać ścieżki prowadzącej do oświecenia. Obudził w ludziach świadomość nieskończoności wszechświata i historyczności. W szerszym kontekście spowodował, że w dziedzinie sztuki powstała nowa estetyka, związana z pustką i spokojem duszy oraz czystością przestrzeni ${ }^{73}$.

Księżyc i jego blask są także ulubionym tematem wielu chińskich poetów ${ }^{74}$. Według autora artykułu „Szczegółowa analiza motywu «księżyca» jako metafory w kulturze chińskiej" ${ }^{75}$ księżyc w poezji jest symbolem rozłąki i ponownego zjednoczenia ${ }^{76}$ oraz tęsknoty za ojczyzną, także tą „małą”, czyli domem, rodzinnymi stronami ${ }^{77}$. Sprawia, że przywołujemy wspomnienia, myślimy o przeszłych czasach. Jak wyżej wspomniano, oznacza także samotność i utratę nadziei ${ }^{78}$.

\section{MITOLOGIA A ŚWIAT WSPÓŁCZESNY}

Chodzi o Chiński Projekt Eksploracji Księżyca (Zhōngguó tànyuè gōngchéng 中国探月工程). Praktycznie wszystkie pojazdy, które są wysyłane w celu zbadania Srebrnego Globu, noszą nazwy pochodzące z mitologii.

\footnotetext{
${ }^{73}$ FU, "Zhōngguó de yuèliang".

${ }^{74} \mathrm{O}$ tym, co symbolizował w poezji epoki Tang, pisze szczegółowo m.in. Aleksandra Olejarz w rozprawie Motyw księżyca $w$ poezji dynastii Tang na przykładzie wybranych dziet Li Baia $i$ Wang Weia (nieopublikowana praca licencjacka, UAM, Katedra Orientalistyki, 2017).

${ }^{75}$ JIE FENG, , «Yueliang》 zai Zhongguo wenhua zhong de yinyu qianxi 《月亮》在中国文化 中的隐喻浅析”. Jiannan Wenxue 剑南文学 2011, nr 11: 144-145, 147, dostęp 25.03.2019, https://www.0011 unwen.com/yishulilun/66404.html.

${ }^{76}$ Por. Opowieść o Pasterzu i Tkaczce - szczegółowa wersja m.in. u Kruppa (Za horyzontem, 339-342).

${ }^{77}$ Nie można nie zacytować w tym miejscu jednego z najsłynniejszych chińskich wierszy, łączącego motyw księżyca i tęsknotę za domem, autorstwa Li Baia (Lǐ Bái 李白, 701-762):

„Przed łóżkiem smugi księżyca blasku

$\mathrm{Na}$ ziemi podobnego do szronu

Unosząc głowę patrzę na księżyc

Spuszczając głowę myślę o domu" (przeł. Aleksandra Olejarz).

${ }^{78}$ FENG, „«Yueliang» zai Zhongguo”.
} 
Pierwszy etap rozpoczął się w 2007 r. umieszczeniem na orbicie Księżyca sondy Chang'e 1 (Cháng'é yīhào 嫦娥一号). Do jej zadań należało wykonanie trójwymiarowych zdjęć powierzchni Księżyca, określenie rodzaju, zawartości i rozmieszczenia pierwiastków i substancji chemicznych w gruncie oraz grubości warstwy gleby, a także zbadanie przestrzeni kosmicznej pomiędzy Ziemią a Księżycem. Podobnie określono obowiązki Chang'e 2 (Cháng'é èrhào 嫦娥一号), którą wystrzelono trzy lata później. Miała ona także monitorować obszar wokół satelity ${ }^{79}$.

W 2013 r. rozpoczęto realizację drugiego etapu, wysyłając na powierzchnię Księżyca za pomocą sondy Chang'e 3 (Cháng'é sānhào 嫦娥三号) łazik o nazwie Jadeitowy Królik (Wang 2015) ${ }^{80}$. W grudniu 2018 r. Chang'e 4 (Cháng'é sihào 嫦娥四号) podejmie próbę lądowania na niewidocznej z Ziemi stronie Księżyca. Kluczowym elementem tej misji było uruchomienie w maju 2018 r. satelity przekaźnikowego Sroczy Most ${ }^{81}$.

Ostatni, trzeci etap będzie polegał na wystrzeleniu w 2019 r. sondy Chang'e 5 (Cháng'é wǔhào 嫦娥五号) i prawdopodobnie w 2020 r. sondy Chang'e 6 (Cháng'é liùhào 嫦娥六号), które będą miały za zadanie zebranie na Księżycu próbek i odesłanie ich statkami powrotnymi na Ziemię ${ }^{82}$.

Kult Słońca, Księżyca, gwiazd i planet nie jest charakterystyczny tylko dla kultury Chin. Rozmaite ludy na wszystkich zamieszkanych kontynentach czciły ciała niebieskie, a ponieważ ich wiedza nie była wystarczająca, różnego rodzaju znane dzisiaj powszechnie zjawiska fizyczne przekładali na swoje możliwości poznawcze, nadając owym ciałom i zjawiskom cechy ludzkie i czyniąc z nich bóstwa. Na przykład królika widzieli na Księżycu nie tylko starożytni Chińczycy, ale także Sasi z północnej Europy, Aztekowie, Majowie oraz Indianie z Południowego Zachodu Stanów Zjednoczonych ${ }^{83}$. Pewnej wyjątkowości chińskiej kulturze i wierzeniom dodaje spe-

79 Data Realise and Information Service System of China's Lunar Exploration Program, „Tànyuè gōngchéng 中国探月工程”, dostęp 13.09.2018, http://moon.bao.ac.cn.

${ }^{80}$ ZHIGANG WANG, „2013 nián 12 yuè 2 rì Zhōngguó chénggōng fāshè Cháng’é sānhào yuèqiú tàncèqì 2013年12月2日中国成功发射嫦娥三号月球探测器”, News 新华网 2.12.2015, dostęp 13.09.2018, http://www.xinhuanet.com/ science/2015-12/02/c_134870023.htm.

${ }^{81}$ Nora TAYLOR RedD, „Chang'e-4: Visiting the Far Side of the Moon”. Space.com, 26.05.2018, dostęp 12.09.2018, https://www.space.com/40715-change-4-mission.html.

${ }^{82}$ Mengmeng WANG (red.), „Cháng’é wǔhào jìhuà zài 2019 nián fāshè jiāng cóng yuèqiú cǎiyàng fănhuí 嫦娥五号计划在2019年发射 将从月球采样返回”, News 新华网, 24.04.2018, dostęp 13.09.2018, http://www.xinhuanet.com/2018-04/24/c_1122736581.htm; „Guójiā Hángtiānjú: jiāng yú 2020 nián zuǒyòu fāshè Cháng’é liùhào. Hángtiān Àihàozhě Wăng 2018 [online].

${ }^{83}$ KRUPP, Za horyzontem, 103. 
cyfika języka chińskiego, który pozwala na fonetyczne kojarzenie rozmaitych postaci i pojęć. Ale jest w nich także czynnik uniwersalny, który łączy tę kulturę z innymi. Jednym z nich jest wspomniany już królik, ale także Księżyc jako natchnienie poetów, symbol kobiety, nostalgii, samotności czy więzi z przeszłością. Niezwykłe jest również to, jak władze Chin wykorzystują elementy tradycyjnej kultury, by w XXI wieku budować tożsamość narodu i przypomnieć o jego dziedzictwie.

\section{BIBLIOGRAFIA}

„Bùtóng bănběn Wú Gāng fá guì de chuánshuō gùshì 不同版本吴刚伐桂的传说故事 [Różne wersje legendy o Wu Gangu ścinającym cynamonowiec]”. Sohu.com 搜狐, 25.01.2018. Dostęp 24.05.2018. http://www.sohu.com/a/218795462 100058695.

CNR News 中央人民广播电台. „Guójiā Hángtiānjú: jiāng yú 2020 nián zuǒyòu fāshè Cháng’é liùhào 国家航天局: 将于2020年左右发射嫦娥六号 [Chińska Narodowa Agencja Kosmiczna: W 2020 roku zostanie wystrzelona Chang'e 6]". Hángtiān Àihàozhě Wăng 航天爱好者网 2016. Dostęp 13.09.2018. http://www.spaceflightfans.cn/tag/嫦娥六号.

Data REAlise AND Information SERVice System of ChinA's LunAR EXPlORATION Program 探 月工程数据发布与信息服务系统. „Tànyuè gōngchéng 中国探月工程 [Projekt eksploracji Księżyca]". Dostęp 13.09.2018. http://moon.bao.ac.cn.

DA YING 笪颖. „Zhōngqiū chī yuèbǐng de lálì 中秋吃月饼的来历 [Skąd wziął się zwyczaj jedzenia ciasteczek księżycowych podczas Święta Środka Jesieni]”. People.cn 人民网, 5.09.2014. Dostęp 11.09.2018. http://history.people.com.cn/n/2014/0905/c388792-25610906.html.

EBerhard, Wolfram. Symbole chińskie. Słownik. Obrazkowy język Chińczyków. Przełożyła Renata Darda. Kraków: Towarzystwo Autorów i Wydawców Prac Naukowych UnIVERSITAS, 1996.

FENG JIE 冯杰. „«Yueliang》 zai Zhongguo wenhua zhong de yinyu qianxi 《月亮》在中国文化 中的隐喻浅析 [Szczegółowa analiza motywu «księżyca» jako metafory w kulturze chińskiej]”. Jiannan Wenxue 剑南文学 2011, nr 11: 144-145, 147. Dostęp 25.03.2019. https://www. 001lunwen.com/yishulilun/66404.html.

FU DAOBIN. 傅道涁. „Zhōngguó de yuèliang jíqí yìshù de xiàngzhēng 中国的月亮及其艺术的象 征 [Chiński Księżyc i jego symbolika w sztuce]. Sohu.com 搜狐, 11.11.2017. Dostęp 25.03.2019. http://www.sohu.com/a/203781849_488759.

Granet, Marcel. Religie Chin. Przełożyła Joanna Rozkrut. Kraków: Wydawnictwo ZnaK 1997.

„Guăng hán gōng 广寒宫 [Pałac rozległego zimna]”. W: Hàn wénxué wăng | Hànyǔ cídiăn 汉文 学网|汉语词典 [Literatura chińska w sieci | Słownik języka chińskiego]. Dostęp 11.09.2018. http://cd.hwxnet.com/view/ogofofkhmehekagj.html.

„Kasja”. W: Encyklopedia PWN. PWN. Dostęp 9.09.2018. https://encyklopedia.pwn.pl/haslo/ kasja;3920895.html.

Krupp, Edwin C. Za horyzontem. Mity i legendy o Stońcu, Księżycu, gwiazdach i planetach. Przełożył Robert M. Sadowski. Warszawa: Prószyński i S-ka SA, 2006.

Liao, Sabrina. Chinese Astrology. Ancient Secrets for Modern Life. New York: Hachette Book Group 2000. Hachette BOOK GROUP. Dostęp 10.09.2018. https://www.hachette bookgroup.com/ titles/sabrina-liao/chinese-astrology/9780759520486/.

Pimpaneau, Jacques. Chiny. kultura i tradycje. Przełożyła Irena Kałużyńska. Warszawa: Wydawnictwo Akademickie Dialog 2001. 
Redd, Nora Taylor. „Chang'e-4: Visiting the Far Side of the Moon”. Space.com, 26.05.2018. Dostęp 12.09.2018. https://www.space.com/40715-change-4-mission.html.

TANG, SANMU. Obchodzimy chińskie święta. Zbiór opowiadań i przepisów kulinarnych. Przełożyła Jadwiga Smulko. Ożarów Mazowiecki: Wydawnictwo Olesiejuk, 2013.

Walters, DereK. Mitologia Chin. Przełożyła Wisława Szkudlarczyk. Poznań: Dom Wydawniczy REBIS 1996.

Wang Mengmeng (red.) 王萌萌编辑. „Cháng’é wǔhào jìhuà zài 2019 nián fāshè jiāng cóng yuèqiú cǎiyàng fănhuí 嫦娥五号计划在2019年发射 将从月球采样返回 [Na 2019 rok zaplanowano wystrzelenie sondy Chang'e 5, która w przyszłości powróci z próbkami z Księżyca]”. News 新华网, 24.04.2018. Dostęp 13.09.2018. http://www.xinhuanet.com/2018-04/24/c_112 2736581.htm.

WANG ZHIGANG 王志 „2013 nián 12 yuè 2 rì Zhōngguó chénggōng fāshè Cháng’é sānhào yuèqiú tàncèqì 2013年12月2日中国成功发射嫦娥三号月球探测器 [2.02.2013 roku Chiny wystrzeliły sondę Chang'e 3]”. News 新华网 2.12.2015. Dostęp 13.09.2018. http://www.xinhuanet.com/ science/2015-12/02/c_134870023.htm.

Wu JINGRONG 吴景荣, CHENG ZHENQIU 程镇球编辑 (red.). New Age Chinese-English Dictionary. Xin shidai han-ying da cidian [新时代汉英大词典]. Beijing 北京: Shangwu Yinshuguan 商务印书馆, 2001.

Wu TIANMing 吴天明. The Study on Chinese Myths. 中国神话研究. Beijing 北京: Central Compilation \& Translation Press 中央编译出版社, 2003.

ZHANGXIU (red). „Guănghángōng de láilì. Cháng'é bènyuè yǐhòu wèishénme zhùzài guănghángōng 广寒宫的来历嫦娥奔月后为什么住在广寒宫 [Historia Pałacu rozległego zimna, czyli dlaczego Chang'e po przybyciu na Księżyc zamieszkała w Pałacu rozległego zimna]”. Lìsȟ̀ qùwén 历史趣闻 2015. Dostęp 10.09.2018. http://www.lishiquwen.com/news/37.html.

\section{CHIŃSKIE MITY I WIERZENIA ZWIĄZANE Z KSIĘŻYCEM}

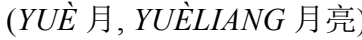

\section{Streszczenie}

Niniejszy artykuł stanowi próbę zgromadzenia w jednym miejscu najpopularniejszych mitów, symboli i opisów postaci związanych z Księżycem. Został podzielony na dwie części, z których pierwsza odnosi się właśnie do legend i przedstawia mieszkańców Srebrnego Globu (Chang'e, zając/królik, ropucha/żaba, Wu Gang) oraz obiekty tam się znajdujące (drzewo cynamonowe, Pałac rozległego zimna). Druga część to próba naukowej weryfikacji opisanych wcześniej wierzeń i mitów. Obejmuje takie zagadnienia, jak kult bóstwa żaby i bóstwa Księżyca w kontekście kobiecości, płodności i nieśmiertelności. Dalej, zajmuje się związkiem Księżyca i cyfry „siedem”. Ostatnie dwie części omawiają krótko święta, które tradycyjny kalendarz chiński łączy z Księżycem (Święto Środka Jesieni oraz Święto Podwójnej Siódemki), oraz Chiński Projekt Eksploracji Księżyca, który jest współczesnym dowodem na przywiązanie Chińczyków do tradycji i ludowych wierzeń (nazwy pojazdów kosmicznych od imion mitycznych postaci).

Słowa kluczowe: Księżyc; Chang’e; ropucha/żaba; zając/królik; Wu Gang; drzewo cynamonowe; siedem. 